\title{
Giant Cell Tumor of Tendon Sheath of Great Toe
}

\section{Surya Bahadur Thapa, Bibek Banskota and Ashok Kumar Banskota}

B \& B Hospital, Lalitpur, Nepal.

\section{ABSTRACT}

Introduction: Giant cell tumor of the tendon sheath is an uncommon benign soft tissue tumor of the tendon sheath and synovium usually affecting the middle aged population. Only 3-10\% of Giant cell tumor of the tendon sheath occur on foot. Of them 5 - $10 \%$ present with erosion of bone.

We present a case of 30 years old male who had Giant cell tumor of the tendon sheath on the foot involving the Flexor Hallucis Longs and Extensor Hallucis Longus and eroding both the phalanges of the right great toe.

Keywords: giant cell tumors; tendon sheath; benign tumor; curettage

\section{INTRODUCTION}

Giant cell tumor of the tendon sheath (GCTTS) is a benign soft tissue tumor of the tendon sheath and synovium ${ }^{1}$. Patients present with a history of painless swelling. An overall incidence is 1 in 50,000 individuals ${ }^{2}$. $3-10 \%$ of GCT-TS occur in the foot and 5-10\% of these erode adjacent bone ${ }^{3}$. This case is of a GCT-TS on the right great toe which involved both the FHL and EHL eroding the proximal and distal phalanges of the great toe. The aim of this case report is to present a rare case with atypical presentation.

\section{CASE REPORT}

A 30 years old gentle man presented with a slow nodular swelling on right great toe for 8 years which was sometimes painful inside his footwears.

Local examination revealed a firm non-tender pea sized nodular swelling (Figure 1) overlying the lateral side of the inter-phalangeal joint of right great toe with normal overlying skin and without any signs of vascular and nerve lesions. Terminal Flexion of the interphalangeal joint was restricted but painless.

Plain x-ray (Figure 2 ) revealed an enlarged soft tissue shadow and centrally located cystic changes on proximal and distal phalanx.

MRI revealed a soft tissue nodular lesion in the right great toe surrounding proximal and distal phalanges measuring $3 \times 2.1 \mathrm{~cm}$ with iso to muscle intensity in $\mathrm{T} 1 \mathrm{~W} 1$, low signal intensity on T2W2 and the slightly high signal intensity on STIR (Figure 3). The lesion was encasing the FHL and EHL. The metatarso-phalangeal joint was found to be normal.

Intraoperatively, a $5 \mathrm{~cm}$ yellowish rubbery tanned mass popped out at the subcutaneous level (Figure 4) encasing both the tendon sheath of FHL and EHL and cavitating the proximal phalanx and distal phalanges which was excised in piece meal. The cavity in the phalanges was curetted thoroughly after

Correspondence: Surya Bahadur Thapa, Department of Orthopedics, B \& B Hospital, Lalitpur, Nepal. Email: suryathapa145@gmail.com 


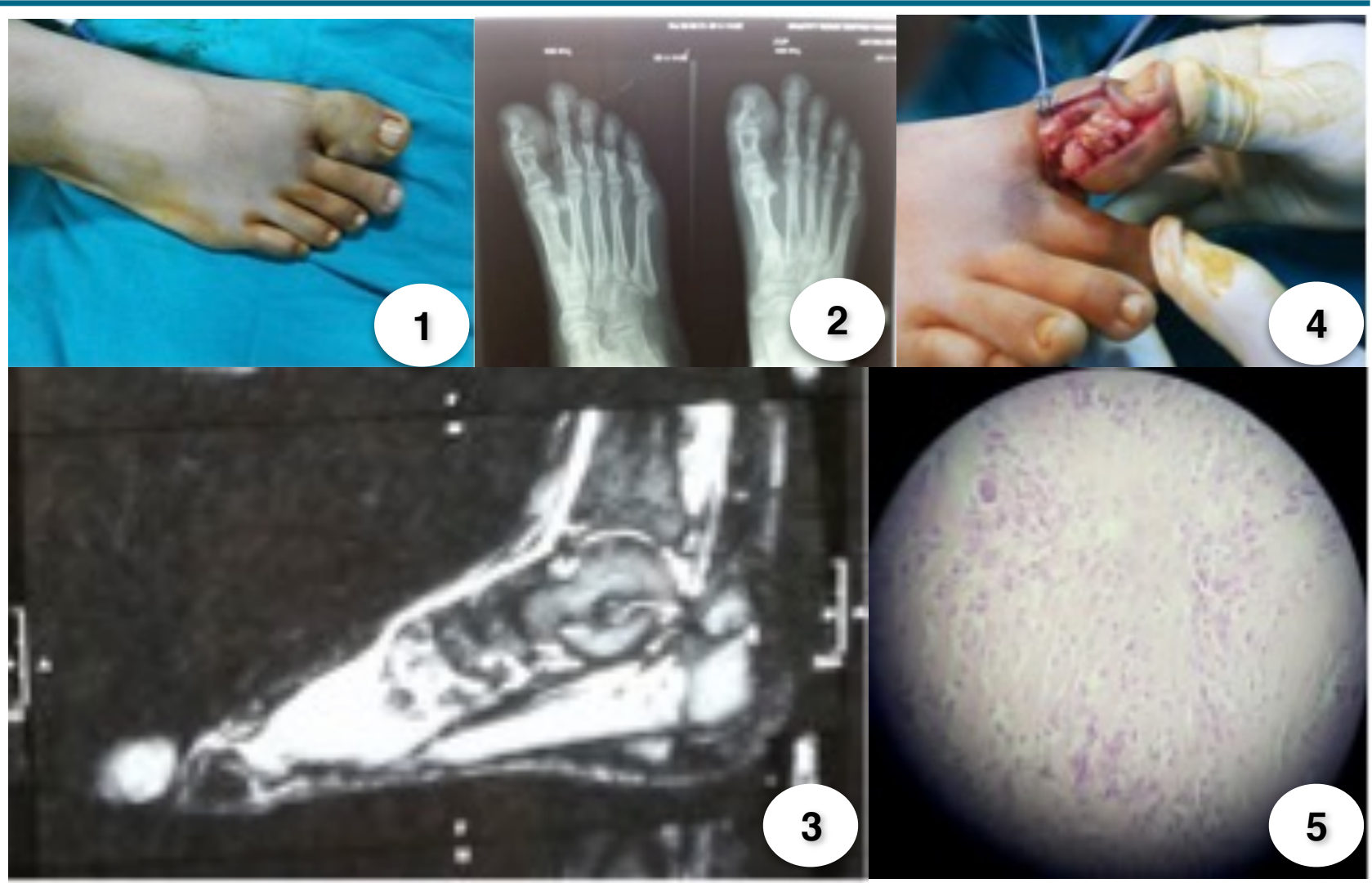

Figures 1 to 5. 1:Clinical appearance of swelling, 2: X-Ray showing lytic lesion, 3: MRI Saggital section, 4:Intraoperative picture and 5: Histopathology.

excision of the lesion and sample was sent for histopathology. Microscopic examination revealed uniformly appearing mononuclear cells with bland round to ovoid nuclei and scattered osteoclast type giant cells (Figure 5). Sheets of foamy macrophages and collections of hemosiderin pigment were also seen. Post operatively he was advised for radiotherapy.

\section{DISCUSSION}

GCT - TS of toes with erosion of the phalanges are rare ${ }^{4}$. It is also known as pigmented villonodular tumour of the tendon sheath (PVNTS) or extra-articular pigmented villonodular tumor of the tendon sheath ${ }^{5}$. They have been divided macroscopically into diffuse or nodular forms. Diffuse type GCT-TS infiltrate and grow as diffuse tumors in large joints, such as the knee. Nodular-type GCT-TS typically present with a painless mass like in this case but more are common in hand ${ }^{1}$. The differential diagnosis of the lesion like this in the foot and ankle is broad ${ }^{3}$. It might be a tumor which arises from adipose tissue, fibrous tissue, fibrohistiocytic, synovium, cartilage/bone, vessels, nerves or other conditions like ganglion cyst, adventitious bursa, gouty tophus, calcific tendinitis.

X-ray usually shows a soft-tissue mass with or without osseous erosion whereas an MRI shows low signal and variable enhancement in $\mathrm{T} 1$ and low signal on $\mathrm{T} 2$ owing to hemosiderin accumulation $^{6,7}$.

The cut surface is variably colored and microscopy reveals an enveloping fibrous capsule, hemosiderin and pigmented foam cells ${ }^{8}$. Recurrence rate is high upto $10 \%{ }^{4}$.

Marginal excision is the treatment of choice. An appropriate balance between resection of tumor and maintenance of function must be 
achieved, keeping in mind to the possibility of recurrence ${ }^{9}$. Radiation therapy is given post excision for tumors with bony involvement, unresectable tumors and margin positive and infiltrative cases ${ }^{10}$.

\section{CONCLUSION}

Nodular PVNS are rare in foot. High degree of suspicion and early treatment is necessary to avoid extension of lesion to bone and other soft tissue.

1. Akahane T, Mori N, Yoshida K. Giant cell tumor of the tendon sheath extending around the patellar tendon and invading the knee joint and tibia: A case report. Oncol Lett. 2014; 8(6):2800-2. DOI:

https://doi.org/10.3892/ol.2014.2561

2. Baker RE, Vezeridis MP. Giant cell tumor of tendon sheath. J Am Podiatr Med Assoc. 1996;86(7):349-50. DOI:

https://doi.org/10.7547/87507315-86-7-349

3. Z Mayet, T Noble, SKM Magobotha. Giant cell tumour of the tendon sheath (GCT-TS) in the foot: A case report. SA Orthopaedic Journal Autumn 2014 | Vol 13 • No 1

4. Adams EL, Yoder EM, Kasdan ML. Giant cell tumor of the tendon sheath: experience with 65 cases. Eplasty. 2012;12:e50.

5. Murphey MD, Rhee JH, Lewis RB, Fanburg-Smith JC, Flemming DJ, Walker EA. Pigmented villonodular synovitis: radiologic-pathologic correlation. Radiographics. 2008;28(5):1493-518. DOI: https://doi.org/10.1148/rg.285085134

6. Karasick D, Karasick S. Giant cell tumor of tendon sheath: spectrum of radiologic findings. SKELETAL RADIOL. 1992;21(4):219-24. DOI:

https://doi.org/10.1007/BF00243061

7. Jelinek JS, Kransdorf MJ, Shmookler BM, Aboulafia AA, Malawer MM. Giant cell tumor of the tendon sheath: MR findings in nine cases. AJR 1994;162(4):919-22. DOI: https://doi.org/10.2214/ajr.162.4.8141018

8. Ushijima M, Hashimoto H, Tsuneyoshi M, Enjoji M. Giant cell tumor of the tendon sheath (nodular tenosynovitis). A study of
207 cases to compare the large joint group with the common digit group. Cancer. 1986;57(4):875-84. DOI: https://doi.org/ 10.1002/1097-0142(19860215)57:4<875::A ID-CNCR2820570432>3.0.CO;2-Y

9. Hosaka M, Hatori M, Smith R, Kokubun S. Giant cell formation through fusion of cells derived from a human giant cell tumor of tendon sheath. J Orthop Sci. 2004;9(6): 581-4.DOI:

https://doi.org/10.1007/s00776-004-0825-0

10. Coroneos CJ, O'Sullivan B, Ferguson PC, Chung PW, Anastakis DJ. Radiation therapy for infiltrative giant cell tumor of the tendon sheath. J. Hand Surg. 2012;37(4):775-82. DOI: https://doi.org/10.1016/j.jhsa. $\underline{2012.01 .011}$ 